\title{
HUBUNGAN PELAKSANAAN SURGICAL SAFETY CHECKLIST DAN KEJADIAN INFEKSI POST OPERASI MAYOR
}

\author{
Widiyaningsih, Program Studi S1 Keperawatan STIKes Karya Husada Semarang \\ e-mail: widy.dianing@gmail.com \\ Eni Kusyati, Program Studi S1 Keperawatan STIKes Karya Husada Semarang \\ e-mail: kusyatieni2014@gmail.com \\ Amri Hidayat Program Studi S1 Keperawatan STIKes Karya Husada Semarang \\ e-mail:noor.aditya21@gmail.com
}

\begin{abstract}
Background: wound postoperative infection (ILO) are infections caused by pathogenic microorganisms that contaminate the wound area during surgery or after surgery. The data from survey by World Health Organization (WHO) found that about ILO cuased infection as 5\% - 34\% of total nosocomial infections. The data from Centers for Disease Control and Prevention cited that annually there was 500,000 surgical site infections (SSI) and that caused 3\% surgical mortality, prolonged length of stay in hospital, and increased medical costs. Objective: to know the correlation of Surgical Safety Checlist Implementation and post operative infection. Research method: the method was quantitative method with cohort analytic survey design. The population were all patients with major surgery at Public Hospital of Tugurejo Semarang periode December 2016 - January 2017 as many as 99 patients.

Result:the result of this study were major surgery mostly have implementation of surgical safety checklist either 81 respondent $(81,8 \%)$ and have no infection incidence were 84 responden $(84,8 \%)$. There was no significant correlation between surgical safety checklist implementation and postoperative infection.
\end{abstract}

Keywords: surgical safety checlist, postoperative infection

\section{Latar Belakang}

Patient safety merupakan suatu upaya memberikan asuhan pasien lebih aman serta mencegah cedera yang diakibatkan oleh kesalahan dalam suatu tindakan atau tidak melakukan tindakan yang seharusnya dilakukan. Hal yang sama diatur dalam Standar Akreditasi Rumah Sakit tahun 2011 dan Peraturan Menteri Kesehatan Nomor 1691/Menkes/Per/VIII/2011 pasal 8 tentang sasaran keselamatan pasien rumah sakit pada ayat 1 dan 2 menyebutkan bahwa setiap rumah sakit wajib mengupayakan pemenuhan sasaran keselamatan pasien. Beberapa sasaran keselamatan pasien meliputi ketepatan identifikasi pasien; peningkatan komunikasi yang efektif; peningkatan keamanan obat yang perlu diwaspadai; kepastian tepatlokasi, tepat-prosedur, tepat-pasien operasi; pengurangan risiko infeksi terkait pelayanan kesehatan; dan pengurangan resiko pasien jatuh (Depkes RI, 2011).

International Patient Safety Goals juga menekankan pentingnya keselamatan pasien serta perawatan anestesi dan bedah (Anaesthesia and Surgical Care) bagi rumah sakit yang terakreditasi Joint Comission International (JCI). Standar sasaran dalam internasional keselamatan pasien (SIKP) adalah mengidentifikasi pasien dengan benar, memastikan sisi pembedahan benar dan prosedur yang benar (JCI, 2011).Surgicalsafety checklist (SSC) yang di rumuskan oleh WHO pada tahun 2007 sebagai tool/alat yang digunakan oleh para klinisi di kamar bedah untuk mengurangi kematian dan komplikasi akibat pembedahan (WHO, 2009).

Pembedahan dalam pelayanan kesehatan bertujuan untuk menyelamatkan nyawa, mencegah kecacatan dan komplikasi. Namun tindakan pembedahan dapat menimbulkan komplikasi hingga membahayakan nyawa pasien (WHO, 2009). Data WHO menyebutkan bahwa selama lebih dari satu abad tindakan pembedahan telah menjadi komponen penting dari perawatan kesehatan di seluruh dunia. Perawatan bedah merupakan bagian integral 
dari perawatan kesehatan di seluruh dunia, dengan perkiraan 234 juta operasi dilakukansetiap tahun (Haynes, et all. 2009).

hasil penelitian di 56 negara pada tahun 2004 diperkirakan Jumlah tindakan pembedahan di dunia sangat tinggi dengan angka 234 juta per tahun yang melebihi angka kelahiran per tahun. Studi pada negara-negara industri, angka komplikasi tindakan pembedahan diperkirakan 3-16\% dengan kematian 0,4-0,8\%. Tingginya angka komplikasi dan kematian akibat pembedahan menyebabkan tindakan pembedahan seharusnya menjadi perhatian kesehatan global. Dengan asumsi angka komplikasi $3 \%$ dan angka kematian 0,5\%, hampir tujuh juta pasien mengalami komplikasi mayor termasuk satu juta orang yang meninggal selama atau setelah tindakan pembedahan per tahun (Weiser et al. 2010).

Rumah sakit di Indonesia mempunyai prosedur tentang tindakan operasi dengan mengacu pada Permenkes 1691 tahun 2011 tentang Keselamatan Pasien Rumah Sakit sebagai standar pedoman bagi penerapan Keselamatan Pasien di rumah sakit. Semua rumah sakit dan tenaga kesehatan yang bekerja di rumah sakit wajib melaksanakan program dengan mengacu pada kebijakan nasional Komite Nasional Keselamatan Pasien Rumah Sakit. Data terkait dengan patient safety pada tahun 2013 di Indonesia didapatkan propinsi DKI Jakarta paling tinggi yaitu 37,9\%, dan Propinsi Jawa Tengah menempati urutan kedua 15,9\%. Data tertinggi ditemukan pada unit penyakit dalam, bedah, dan anak yaitu sebesar $56,7 \%$, sedangkan untuk pelaporan KNC lebih banyak sebesar 47,6\% dibandingkan KTD sebesar 46,2\% (KKP-RS, 2012).Data tentang KTD dan KNC di Indonesia masih jarang ditemukan karena kurang optimalnya standar pelayanan kesehatan di Indonesia (Depkes RI, 2012).

Infeksi luka operasi (ILO) adalah infeksi yang timbul disebabkan oleh mikroorganisme patogen yang mengkontaminasi daerah luka operasi pada saat berlangsungnya operasi atau sesudah operasi (Andi Kurnia, 2013). Data dari WHO ditemukan ILO menyebabkab infeksi 5\% - 34\% dari total infeksi nosokomial berasal dari.Pusat Pengendalian dan Pencegahan Penyakit memperkirakan 500.000 infeksi situs bedah (SSI) terjadi setiap tahun dan account untuk 3\% kematian bedah, berkepanjangan panjang tinggal di rumah sakit, dan peningkatan biaya medis ( Diaz, 2015 ). Tujuan penelitian ini adalah mengetahui hubungan pelaksanaan surgical safety checklist dan kejadian infeksi post operasi mayor.

\section{METODE PENELITIAN}

Jenis penelitian adalah quantitatif dengan desain survey analitik cohort. Populasi penelitian adalah seluruh pasien operasi bedah mayor di RSUD Tugurejo Semarang periode Desember 2016 - Januari 2017 sebanyak 99 responden. Sampel penelitian sebanyak 49 responden dengan kriteria inklusi: Pasien post operasi bedah mayor yang dirawat di RSUD Tugurejo Semarang, bersedia menjadi responden penelitian. Kriteria eksklusi: Pasien operasi bedah minor, pasien bedah mayor yang tidak bersedia menjadi responden penelitian.. Instrumen penelitian menggunakan surgical safety checklist dari WHO, 2009 dengan kriteria checklist superficial incision SSI oleh the national nosocomial surveillence infection (NNIS) and lembar observasi infeksi. Analisis data menggunakan uji statistik Chi Square.

\section{HASIL DAN PEMBAHASAN \\ Hasil Penelitian}

\section{a. Pelaksanaan surgical safety checklist checklist}

Tabel 1.1. Distribusi frekuensi pelaksanaan surgical safety checklist pada operasi mayor

\begin{tabular}{lcc}
\hline $\begin{array}{l}\text { Pelaksanaan surgical } \\
\text { safety checklist }\end{array}$ & $\sum$ & $(\%)$ \\
\hline Baik & 81 & 81.8 \\
Kurang baik & 18 & 18.2 \\
\hline Total & 99 & 100.0 \\
\hline
\end{tabular}

Hasil penelitian menunjukkan bahwa operasi mayor sebagian besar mempunyai pelaksanaan surgical safety checklist baik sebanyak 81 responden $(81,8 \%)$ dan sebagian kecil mempunyai pelaksanaan pelaksanaan surgical safety checklist kurang baik sebanyak 18 responden $(18,2 \%)$.

\section{b. Kejadian infeksi}

Tabel 1.2. Distribusi frekuensi kejadian infeksi pada operasi mayor

\begin{tabular}{lcc}
\hline \multicolumn{1}{c}{ Kejadian infeksi } & $\sum$ & $(\%)$ \\
\hline Infeksi & 15 & 15.2 \\
Tidak infeksi & 84 & 84.8 \\
\hline Total & 99 & 100.0 \\
\hline
\end{tabular}


Hasil penelitian dapat diketahui bahwa operasi mayor sebagian besar mempunyai kejadian responden $(84,8 \%)$ dan sebagian kecil terjadi infeksi kategori tidak infeksi sebanyak 84 infeksi sebanyak 15 responden $(15,2 \%)$.

c. Hubungan pelaksanaan surgical safety checklist dan kejadian infeksi post operasi mayor Tabel 1.3 Hubungan pelaksanaan surgical safety checklist dan kejadian infeksi post operasi mayor Pelaksanaan surgical safety checklist

\begin{tabular}{ccccccccc}
\cline { 2 - 6 } & $\mathrm{N}$ & $\%$ & $\mathrm{~N}$ & $\%$ & $\mathrm{~N}$ & $\%$ & & \\
\hline Baik & 10 & 10,1 & 71 & 71,7 & 81 & $81,80 \%$ & \multirow{2}{*}{0,660} & 0,198 \\
Kurang baik & 2 & 5,1 & 13 & 13,1 & 18 & 18,2 & & \\
\hline Jumlah & 12 & 15,2 & 84 & 84,8 & 99 & 100 & & \\
\hline
\end{tabular}

Dari hasil olah data dengan Chi Square, maka didapatkan nilai Continuity Correction sebesar 1.660 dengan $\mathrm{p}$ value $0,198<0,05$ maka dapat disimpulkan tidak ada hubungan yang bermakna antara pelaksanaan surgical safety checklist dan kejadian infeksi post operasi mayor.

\section{Pembahasan}

\section{a. Pelakssanaan surgical safety checklist checklist}

Berdasarkan hasil penelitian dapat diketahui bahwa operasi mayor sebagian besar mempunyai pelaksanaan pelaksanaan surgical safety checklist checklist baik sebanyak 81 responden $(81,8 \%)$ dan sebagian kecil mempunyai pelaksanaan pelaksanaan surgical safety checklist kurang baik sebanyak 18 responden (18,2\%). Dalam penerapannya checklist ini dibagi menjadi bagian-bagian yang sesuai dengan tahapan perawatan di jalur bedah (pra operasi, operasi, pemulihan atau perawatan intensif dan pasca bedah) dan itu adalah multi disiplin yang dilakukan oleh dokter, perawat, ahli bedah, ahli anestesi dan asisten operasi semua bertanggung jawab untuk menyelesaikan bagian dari checklist. Surgical safety sistem yang menggunakan checklist untuk memantau keselamatan pasien merupakan suatu alat atau sarana yang sangat penting dalam penerapan patient safety atau keselamatan pasien khusunya di dalam ruang operasi.

Fase sign In dilakukan sebelum induksi anestesi dilakukan, koordinator akan memeriksa secara verbal terkait identitas pasien apakah telah dikonfirmasi, prosedur dan sisi operasi sudah benar, sisi yang akan dioperasi telah ditandai, persetujuan untuk operasi telah diberikan, pulseoksimeter pada pasien berfungsi. Koordinator dengan profesional anestesi mengkonfirmasi risiko pasien apakah pasien ada risiko kehilangan darah, kesulitan jalan nafas, reaksi alergi (Hermawan, 2014).

\section{b. Kejadian infeksi}

Berdasarkan hasil penelitian dapat diketahui bahwa post operasi mayor sebagian besar mempunyai kejadian infeksi kategori tidak infeksi sebanyak 84 responden $(84,8 \%)$ dan sebagian kecil terjadi infeksi sebanyak 15 responden $(15,2 \%)$. Infeksi disebabkan suatu organisme yang menginvasi jaringan atau cairan tubuh dengan adanya suatu gejala klinis baik lokal maupun sistemik. Salah satu infeksi yang sering ditemukan di rumah sakit adalah infeksi nosokomial dimana infeksi terjadi selama pasien mendapatkan perawatan di rumah sakit. Gejala dapat muncul selama pasien dirawat atau setelah selesai dirawat. Secara umum, gejala infeksi nosokomial yang terjadi kurang dari 72 jam menunjukkan bahwa masa inkubasi penyakit telah terjadi sebelum pasien masuk rumah sakit. Namun jika infeksi menunjukkan gejala setelah 72 jam pasien berada dirumah sakit baru hal ini termasuk kedalam infeksi nosokomial. Penyebab infeksi nosokomial dapat diperoleh dari dalam (infeksi endogen) ataupun luar tubuh penderita. Mikroorganisme yang semula memang sudah ada didalam tubuh (infeksi endogen) dapat berpindah ke tempat baru (self infection) atau auto infection. Infeksi yang disebabkan oleh mikroorganisme yang berasal dari rumah sakit dan dari satu pasien ke pasien lainnya disebut dengan infeksi eksogen (cross infection) (Yudhityarasati, 2007).

Infeksi luka operasi (ILO) adalah infeksi yang timbul disebabkan oleh mikroorganisme patogen yang mengkontaminasi daerah luka operasi pada saat berlangsungnya operasi atau 
sesudah operasi. (Andi Kurnia, 2013). ILO atau Infeksi Tempat Pembedahan (ITP)/ Surgical Site Infection (SSI) dapat terjadi dalam 30 hari paska operasi atau dalam kurun 1 tahun apabila terdapat implant dan terjadi pada luka operasi atau organ/ruang yang terkait daerah operasi. Mikroorganisme yang menyebabkan ILO berasal dari pasien, dokter dan tim, lingkungan, dan termasuk juga instrumentasi (Hidayat NN, 2009). Hasil penelitian dapat diketahui bahwa operasi mayor sebagian kecil terjadi infeksi sebanyak 15 responden $(15,2 \%)$. Hal itu dapat dilihat dari hasil observasi terlihat pembengkakan dan kemerahan pada luka operasi sebanyak $6 \%$ responden.

\section{c. Hubungan pelaksanaan surgical safety checklist dan kejadian infeksi post operasi mayor}

Hasil analisa data dapat disimpulkan bahwa tidak ada hubungan yang bermakna antara pelaksanaan surgical safety checklist dan kejadian infeksi post operasi mayor. Penelitian yang dilakukan oleh Haley dalam Iwan 2008 disimpulkan bahwa waktu perawatan sebelum operasi yang bertambah lama akan meningkatkan resiko terjadinya infeksi nosokomial secara signifikan. Perawatan lebih dari 7 hari pre operasi akan meningkatkan kejadian infeksi pasca bedah dan kejadian tertinggi didapat pada lama perawatan $7-13$ hari (Hadibrata, 1989). Hasil penelitian yang lain infection rate kira-kira 2 kali lebih besar setelah dirawat 2 minggu dan 3 kali lebih besar setelah dirawat selama 3 minggu dibandingkan bila dirawat 1-3 hari sebelum operasi.

Infeksi luka operasi (ILO) adalah infeksi yang timbul disebabkan oleh mikroorganisme patogen yang mengkontaminasi daerah luka operasi pada saat berlangsungnya operasi atau sesudah operasi (Andi Kurnia, 2013). ILO dapat terjadi pada luka operasi atau organ/ruang yang terjadi dalam 30 hari paska operasi atau dalam kurun 1 tahun jika terpasang implant. Penyebab infeksi ILO dapat berasal dari pasien, dokter dan tim, lingkungan, dan termasuk juga instrumentasi (Hidayat NN, 2009).

Hasil penelitian dapat diketahui bahwa operasi mayor yang mempunyai pelaksanaan surgical safety checklist baik tetapi masih mengalami infeksi dan pelaksanaan kurang baik tetapi tidak terjadi infeksi hal tersebut dikarenakan surgical safety checklist hanyalah langkah atau prosedur dalam menjalankan operasi bedah mayor sehingga hal tersebut pasti akan dilakukan semua walau tidak disebutkan pada saat peneliti melakukan penelitian, sehingga dapat disimpulkan surgical safety checklist tidak ada hubungannya dengan kejadian infeksi pasca operasi bedah mayor.

Hasil Penelitian berbeda dengan penelitian yang dilakukan oleh Agus Pujianto (2014) tentang Pengaruh Implementasi Surgical Safety Checklistterhadap Keselamatan Pasien Bedah Mata di Kamar Bedah RS Mata "Dr. Yap" Yogyakarta. Hasil penelitian tingkat keselamatan pasien pada kelompok kontrol mencapai $93 \%$, Tingkat Keselamatan pasien pada kelompok eksperimen mencapai $100 \%$. Ada pengaruh Implementasi Surgical Safety Checklist terhadap keselamatan pasien bedah mata di kamar bedah RS Mata "Dr. Yap" Yogyakarta. Dari hasil uji Chi Square Fisher didapatkan nilai signifikansi (p-value) 0,001 < 0,05 . Tingkat perbedaan keselamatan pasien antara kelompok kontrol dan kelompok eksperimen sebesar $7 \%$.

\section{Kesimpulan}

Tidak ada hubungan yang bermakna antara pelaksanaan surgical safety checklist checlistdan kejadian infeksi post operasi mayor.

\section{Daftar Pustaka}

Depkes RI. 2011. Upaya Peningkatan Mutu Pelayanan Rumah Sakit. (konsep dasar dan prinsip). Jakarta: Depkes RI

Diaz.V. 2015. Surgical Site Infection and Prevention Guidelines: A Primer for Certified Registered Nurse Anesthetists. AANA Journal Vol. 83, No. 1

Haynes ,A.B. 2009. A Surgical Safety Checklist to Reduce Morbidity and Mortality in a Global Population. The New England Journal of Medicine Downloaded from nejm.org .

Hidayat, NN. 2009. Metode Penelitian Keperawatan dan Teknik Analisa Data.Jakarta : Salemba Medika

Hermawan ,H. 2014. Gambaran Penerapan Surgery Patient Savety Fase Sing Out Pada Pasien Post Operasi Bedah Mayor Di Instalasi Bedah Sentral RSUD Kebumen. 
Jurnal Ilmiah Kesehatan Keperawatan, Volume 10, No. 3

, Weiser TG, Haynes AB, Dziekan G, Berry WR, Lipsitz SR, Gawande AA. 2010. Effect of a 19-item surgical safety checklist during urgent operations in a global patient population. Ann Surg;251(5):976-8

JCI., 2011, Joint Commission International Accreditation Standards for Hospitals, 4th Edition. Oakbrook Terrace, Illinois USA

Peraturan Menteri Kesehatan Nomor 1691/Menkes/Per/VIII/2011 pasal 8 tentang sasaran keselamatan pasien rumah sakit

Weiser TG, Haynes AB, Dziekan G, Berry WR, Lipsitz SR, Gawande AA. 2010. Effect of a 19-item surgical safety checklist during urgent operations in a global patient population. Ann Surg;251(5):976-8

World Health Organitation Collaborating Centre for Patient Safety Solutions. 2009. Patient Safety

Solutions

Preamble.www.who.int/entity/patientsafety / solutions/patientsafety/preamble.pdf. Diunduh 7 September 2016. 
